Journal of Agricultural Sciences
(Tarim Bilimieri Dergisi)

\title{
Multi-Environment Analysis of Grain Yield and Quality Traits in Oat (Avena sativa L.)
}

\author{
Özge Doğanay ERBAŞ KÖSE

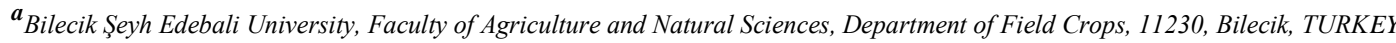

ARTICLE INFO

Research Article

Corresponding Author: Özge Doğanay ERBAŞ KÖSE, E-mail: ozgedoganay.erbas@bilecik.edu.tr

Received: 09 March 2020 / Revised: 18 May 2020 / Accepted: 19 May 2021 / Online: 25 March 2022

\section{ABSTRACT}

Oat is used for food, in animal feeding and non-food products. Twentyfive oat genotypes were evaluated at six different environments to determine high-yielding, good-quality and stable genotypes Experiments were conducted in randomized blocks design with 4 replications. Grain yield, plant height, test weight, thousand-grain weight, screening percentage, groat percentage, protein, $\beta$-glucan and starch contents were evaluated for 25 oat genotypes. Genotype, environment and genotype $\times$ environment interaction had extremely important effects on yield and quality of oat grains. The additive main effects and multiplicative interactions analysis disclosed important genotype and environmental effects in addition to genotype by environmental interaction according to grain yield. Using AMMI analysis, three promising oat genotypes (G1, G3 and G7) were defined in comparison to the cultivars and these genotypes had 4.03, 3.77 and $3.70 \mathrm{t} \mathrm{ha}^{-1}$, respectively. AMMI-2 biplot revealed that E6 was the most discriminating environment for grain yield of oat genotypes. Genotypeby-trait (GT) biplot explained $54.9 \%$ of total variation. Grain yield were positive associated with all traits except plant height. G1, G3 and G7 genotypes, which showed the best performance and higher stability, also had good quality traits.

Keywords: AMMI, Biplot, $\beta$-glucan, Grain yield, Oat, Protein

(C) Ankara University, Faculty of Agriculture

\section{Introduction}

Oat (Avena sativa L.) is a multi-purpose product used in both human nutrition and animal feeding. It is quite less selective in soils and climate, thus can reliably be grown in infertile soils and cool and humid climates (Sánchez-Martín et al. 2014). World oat cultivation is usually practiced between $35^{\circ}$ and $65^{\circ}$ North latitudes. From 1978 to 2018 , world oat production decreased from 48.3 million tons to 23.1 million tons (FAO 2018). Despite decreasing production quantities, there is a growing interest in oat production just because of positive impacts on human health. Therefore, oat breeders focus not only on yield and morphological traits, but also on nutritional and industrial quality traits in selection of superior oat genotypes. Oat grains have greater nutritional values than many other unfortified cereals and also quite rich in protein, $\beta$-glucan, carbohydrate, fat, vitamins, minerals, some antioxidants and anti-carcinogenic substances, thus have several positive impacts on human health (Michels et al. 2020).

Oat grains to be used for animal feeding and human nutrition may exhibit diverse variation in grain quality parameters. Price is mostly designed by quality parameters. However, recent researches have mostly focused on herbage yield, stress tolerance and disease resistance rather than grain quality. Thousand-grain weight, test weight, screenings percentage, groat percentage, protein content, fat content and $\beta$-glucan content are the most important physical and chemical parameters designating the purpose of use of the grains. Besides grain yield, these quality attributes are also significantly influenced by the genotype, environmental conditions and the interaction of these two components (Doehlert et al. 2001; Peterson et al. 2005; Mut et al. 2018; Mohammadnia et al. 2021). Genotype-environment interactions (GEI) reason genotypes to realize differently in diverse environments (Crossa 1990; Blagojević et al. 2017). The aim of the breeders is not only to quantify GEI, but also to find the most suitable growing environment for their genotype (Yan \& Tinker 2006). An ideal stable genotype is one that performs for agronomic and quality in an extensive range of environments resulting well achievement regardless of changes in environmental conditions. Zobel et al. (1988) reported that to predict phenotypic responses to environmental changes of studied genotypes, genotype $\times$ environment interaction is frequently evaluated by the AMMI (additive main effects and multiplicative interaction) model. This model combines that the analysis of variance (ANOVA) with additive parameters and the principal component analysis (PCA) with multiplicative parameters in only one analysis. The AMMI biplot display together both main and interaction effects for environments and genotypes. In addition, provides a single analysis of the genotype by environment interaction (Gauch \& Zobel 1996). 
The objectives of the study were (I) to evaluate grain yield and important quality traits of different oat genotypes at six locations, (II) to select stable and high yielding oat genotypes for the grain yield.

\section{Material and Methods}

\subsection{Plant material, location and experimental design}

In present study, 23 advanced lines and two registered cultivars were used as the plant material (Table 1). Experiments were conducted during 2015-2016 growing season at 6 different locations (Amasya - 40 $50^{\prime} \mathrm{N}, 35^{\circ} 27^{\prime} \mathrm{E}$, elevation 610 m; Çorum- $39^{\circ}$

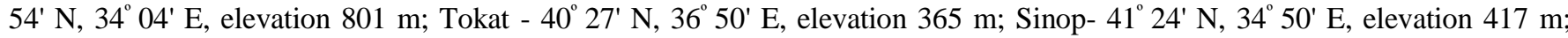

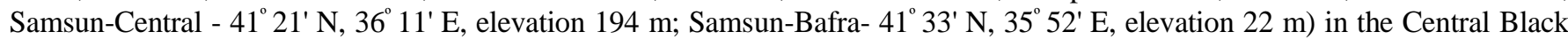
Sea Region of Turkey. Location, climate and soil parameters of the experimental sites are provided in Table 2 . Climate data were obtained from the Turkish State Meteorogical Services in the period (Anonymous 2016).

Table 1- Code genotype / pedigrees of 25 oat studied in six environments

\begin{tabular}{ll}
\hline Code & Genotype /pedigree \\
\hline G1 & IA B605 X//Dane/Newdak \\
G2 & Morton/IL99-8803 \\
G3 & LA966BIB77/TX96M1398 \\
G4 & Horizon 321/LA9819IBI-75-2-B \\
G5 & LA966BIB119-1(FL9595MEO29/TX93M2107)/UPF94H1400-6-1-1 \\
G6 & FL03224 F1 (UPF94174-1/FL9605-A6-B4(FLLA89104-U1-G7/GA8702-C13-4-7))/FL03021 F1 (UFRGS 02B6193-9-4/OA 1039-1) \\
G7 & Sesqui/WIX7571-1//ND010426 \\
G8 & FL0206FSB-34-S2/FL06033 F1(Horizon 474/IL 3555) \\
G9 & LA02018SBSBS5-B-S1 / MN02124 \\
G10 & UFRGS16/UPF16 \\
G11 & LA99017SBSBSB-275-B-S2) \\
G12 & TAMO405/LA99016 \\
G13 & 833-99AB118*2/LA604 \\
G14 & UFRGS 028152-1/LA97006GSB-59-2-4-SBS1 \\
G15 & FL03001BSB-S7(LA9339/Bw3996/FL0740 F1(FL0105FSBSBS20-B-S2 (TX97C1168/IA 91462-45-1-6)/IL 2838) \\
G16 & SD030888-19//SD030888-19/ND030349 \\
G17 & FL03129-Ab3/Bw 4899/UPF96146-5-7-2/FL0846 /FL0742 /IL 2838 \\
G18 & Stallion//OA1021-1/SD97575-29-115 \\
G19 & TAMO386ERB/TX83Ab2923 \\
G20 & UPF90H400/UFRGS16 \\
G21 & ND000811/ND980671 \\
G22 & WIX7535-9/WIX7395-4 \\
G23 & LA02029SBSBS48/UFRGS 028153-2 \\
G24 & Seydişehir (Check) \\
G25 & Kahraman (Check) \\
\hline
\end{tabular}

Table 2- Location, soil and climate traits of testing environments

\begin{tabular}{|c|c|c|c|c|c|c|c|}
\hline \multirow[t]{4}{*}{ Location traits } & $\begin{array}{l}\text { Environment } \\
\text { Code }\end{array}$ & $\begin{array}{c}\text { Amasya } \\
\text { E1 }\end{array}$ & $\begin{array}{c}\text { Çorum } \\
\text { E2 }\end{array}$ & $\begin{array}{c}\text { Tokat } \\
\text { E3 }\end{array}$ & $\begin{array}{l}\text { Sinop } \\
\text { E4 }\end{array}$ & $\begin{array}{c}\text { Samsun1 } \\
\text { E5 }\end{array}$ & $\begin{array}{c}\text { Samsun2 } \\
\text { E6 }\end{array}$ \\
\hline & Latitude $(\mathrm{N})$ & $40^{\circ} 50^{\prime}$ & $39^{\circ} 54^{\prime}$ & $40^{\circ} 27^{\prime}$ & $41^{\circ} 24^{\prime}$ & $41^{\circ} 21^{\prime}$ & $41^{\circ} 33^{\prime}$ \\
\hline & Longitude (E) & $35^{\circ} 27^{\prime}$ & $34^{\circ} 04^{\prime}$ & $36^{\circ} 50^{\prime}$ & $34^{\circ} 46^{\prime}$ & $36^{\circ} 11^{\prime}$ & $35^{\circ} 52^{\prime}$ \\
\hline & Altitude (m) & 610 & 801 & 365 & 417 & 194 & 22 \\
\hline \multirow[b]{2}{*}{ Soil Traits } & Soil type & Sandy loam & clay loam & clay loam & clay loam & clayey & Sandy loam \\
\hline & Organic matter (\%) & 0.99 & 1.87 & 2.89 & 3.11 & 1.45 & 0.98 \\
\hline Climate traits & Mean temperature $\left({ }^{\circ} \mathrm{C}\right)$ & 11.7 & 11.8 & 7.7 & 13.1 & 15.5 & 14.2 \\
\hline 1 October 2015 & Total rainfall $(\mathrm{mm})$ & 419.7 & 529.1 & 439.2 & 661.3 & 800.6 & 811.6 \\
\hline 31 July 2016 & Relative humidity (\%) & 65.6 & 66.2 & 74.6 & 66.5 & 66.1 & 82.0 \\
\hline
\end{tabular}

Samsun1: Samsun- Center; Samsun2: Samsun- Bafra

Experiments at all environments were conducted in randomized complete block design with four replications. Sowings were performed between 1 October and 15 November the year 2015. Each genotype was grown in a six row plot of $7.2 \mathrm{~m}^{2}$ with a $0.20 \mathrm{~m}$ row distance and a sowing density of 500 seeds $\mathrm{m}^{-2}$. For all plots in locations were fertilized the $31.3 \mathrm{~kg} \mathrm{~N}$ and 80.0 $\mathrm{kg} \mathrm{P}$ per ha (as di-ammonium phosphate) with sowing. And then $28.7 \mathrm{~kg} \mathrm{~N} \mathrm{ha}^{-1}$ (as ammonium sulphate) was added to complete $60 \mathrm{~kg} \mathrm{ha}^{-1}$ of $\mathrm{N}$. Finally, from urea fertilizer was applied as $60 \mathrm{~kg} \mathrm{~N}$ per ha at the beginning of stem elongation stage. Herbicides (Tribenuran-metil (DF) 75\%) were used for weed control throughout the experiments and plants were grown under rain-fed conditions without irrigation. Samples of all the plots were hand harvested close to the ground by hand using with a sickle in July at all locations. Then these samples were threshed by plot threshing machine. 


\subsection{Grain yield, plant height, physical and chemical analyses}

Following the harvest and threshing, grains of each plot were weighed and resultant values were converted into grain yield (GY) per hectare (ton). The Plant Height (PH) of each genotype was measured from the soil surface to panicle end: the mean measurement of 10 randomly plants were taken for each plot, excluding border plants. Test Weight (TW) was determined in accordance with 55-10 Approved Methods (AACC 2000). Thousand-grain weight (TGW) was determined by weighing 1000 seeds counted with seed counting device (Chopin technologies-Numigral). For screenings percentage (SP), $50 \mathrm{~g}$ samples were shaken over $2 \mathrm{~mm}$ sieve for 20 seconds and the grains passed through sieve openings were weighed and proportioned to total grain weight. For groat percentage (GP), $20 \mathrm{~g}$ grain sample was manually dehulled and dehulled grains were weighed and proportioned to total weight.

Oat grains separated for chemical analyses were freed of any foreign materials, ground in a hammer mill as to pass through $0.5 \mathrm{~mm}$ sieve. Ground samples were preserved in a fridge at $+4{ }^{\circ} \mathrm{C}$ until the analyses. All determinations were conducted in duplicate. Protein (\%, Nx6.25) contents were determined according to AACC International Methods 46-30.01, respectively (AACC 2000). $\beta$-glucan, and starch contents of samples were determined with the aid of enzymatic test kits (Megazyme International, Bray, Ireland) according to AACC Approved Methods 32-23.01 and 76-13.01, respectively (AACC 2000). Results were expressed as the mean on dry weight basis.

\subsection{Statistical analysis}

In variance analysis, each location was considered as an environment and combined analysis was conducted over six environments. To determine the size of the main effects of variation and their interaction on each trait was applied a two-way fixed effect model. Tukey post-hoc test was conducted to indicate the statistically different means. In the study, the tested environments were abbreviated as E1-E6, which were E1: Amasya, E2: Çorum, E3: Tokat, E4: Sinop, E5: Samsun-Center, E6: Samsun-Bafra, respectively. ANOVA analysis for the all traits data of 25 genotypes in 6 environments and AMMI analysis for the grain yield were calculated using SAS (1998).

For grain yield, AMMI model was applied to determine high yielding and stable genotypes, and specific and wide adaptation (Gauch 1993). The AMMI analysis was applied in based on the following model (Crossa 1990) (Equation 1):

$Y i j=\mu+\mathrm{gi}+\mathrm{ej}+\sum_{k=1}^{n} \lambda k \alpha i k \gamma j k+e i j$

Where: Yij, is the yield of the $i$ th genotype in the $j$ th environment; $\mu$, is the general mean; gi, is the $i$ th genotype mean deviation; $e j$, is the $j$ th environment mean deviation; $\lambda \mathrm{k}$, is the square root of the eigen value of the PCA axis $k$; $\alpha i k$ and $\gamma j k$, are the principal component scores for PCA axis $k$ of the $i$ th genotype and the $j$ th environment, respectively and $e i j$ is the residual (Zobel et al. 1988).

As described by Purchase et al. (2000) the AMMI stability values (ASVs) were used to compare the stability of genotypes (Equation 2):

$A S V=\sqrt{\left[\frac{S S_{I P C A 1}}{S S_{I P C A 2}} \times\left(I P C A_{1}\right)\right]^{2}+\left(I P C A_{2}\right)^{2}}$

Where: SS, was the sum of squares; IPCA1 and IPCA2, were the genotypic scores in the AMMI model. The higher the IPCA score, either negative or positive, the more particularly adapted a genotype is to specific environments. Lower the AMMI stability values show more stable genotype across environments. The AMMI stability value was the distance from zero in a two-dimensional scatter plot of IPCA1 and IPCA2 scores. Based on the rank (R) of mean grain yield of genotypes (Yi), denoted (RYi) across environments and the rank of AMMI stability value (RASVi), Genotype Selection Index (GSI) was calculated for each genotype According to Farshadfar \& Sutka (2003), genotype selection index combines both mean yield and stability in a single criterion (Equation 3). Genotypes with low this value have high average yield and high stability.

$G S I_{i}=R A S V_{i}+R Y_{i}$

Biplot graphs were generated to assess genotypes, environments and GEI, and to put forth the most stable genotypes with the prominent traits in each environment. The Figure 1A introduced by AMMI analysis based on grain yield and the Figure 1B introduced that Biplot analysis of GEI based on AMMI 2 model for the first two interactions principal component scores. Data were also graphically analyzed by the genotype $\times$ trait biplot method (Figure 1C) by Yan $\&$ Tinker (2006). Significance levels in graphs were identified based on vector angles of biplot graphs. Principle component analysis was composed of two principle components (PC1 and PC2). Total variance explanation levels close to $100 \%$ indicate high variance explanation coefficients for these parameters (Yan \& Tinker 2006). 


\section{Results and Discussion}

Results of combined variance analysis over 6 environments are provided in Table 3 . The effects of genotype, environment and their interactions on grain yield, plant height and all quality traits were highly significant $(\mathrm{P}<0.01)$.

Table 3- Combined analysis of variance for investigated traits of 25 oat tested across six environments

\begin{tabular}{|c|c|c|c|c|c|c|c|c|c|}
\hline \multirow{3}{*}{ Paremeter } & \multicolumn{7}{|c|}{ Source $(d f)$} & \multirow{3}{*}{ Error } & \multirow{3}{*}{$C V$} \\
\hline & \multicolumn{2}{|c|}{ Genotypes $(G)(24)$} & \multicolumn{2}{|c|}{ Environments $(E)(5)$} & \multirow{2}{*}{$\frac{\operatorname{Rep} / E(18)}{M S}$} & \multicolumn{2}{|c|}{$\underline{G \times E(120)}$} & & \\
\hline & $M S$ & TSS\% & $M S$ & TSS\% & & $M S$ & TSS\% & & \\
\hline GY & $6.82 * *$ & 16.7 & $66.83 * *$ & 51.3 & 0.57 & $1.74 * *$ & 32.0 & 0.11 & 10.14 \\
\hline PH & $2471.91 * *$ & 42.4 & $7046.59 * *$ & 31.3 & 83.31 & $272.27 * *$ & 26.3 & 42.65 & 7.77 \\
\hline TW & $70.92 * *$ & 17.8 & $693.60 * *$ & 55.6 & 17.09 & $19.12 * *$ & 26.6 & 5.78 & 5.72 \\
\hline TGW & $116.99 * *$ & 18.1 & $327.33 * *$ & 17.7 & 5.13 & $48.85 * *$ & 64.2 & 8.77 & 8.91 \\
\hline SP & $245.90 * *$ & 25.0 & $429.92 * *$ & 10.9 & 14.94 & $87.65 * *$ & 64.1 & 6.93 & 3.11 \\
\hline GP & $33.32 * *$ & 14.6 & $642.67 * *$ & 79.4 & 5.12 & $5.26^{* *}$ & 6.0 & 3.26 & 2.4 \\
\hline $\mathrm{PC}$ & $3.11 * *$ & 4.2 & $195.30 * *$ & 88.2 & 0.24 & $0.95 * *$ & 7.6 & 0.28 & 4.46 \\
\hline$\beta C$ & $0.45 * *$ & 10.9 & $10.52 * *$ & 80.1 & 0.05 & $0.12 * *$ & 9.0 & 0.07 & 6.72 \\
\hline SC & $52.87 * *$ & 10.1 & $943.85^{* *}$ & 65.8 & 3.51 & $42.94 * *$ & 24.1 & 18.96 & 5.48 \\
\hline
\end{tabular}

**: Significant at the $\mathrm{P}<0.01$ probability level; MS: Mean squares; TSS\%: percent of total sum of squares; CV: Coefficient of variation; df: degree of freedom; GY: Grain yield; PH: Plant height; TW: Test weight; TGW: Thousand-grain weight; SP: Screenings percentage; GP: Groat percentage; PC: Protein content; $\beta C$ : $\beta$-glucan content; SC: Starch content

The ANOVA also indicated that out of the total sum of squares, 16.7, 51.3 and $32.0 \%$ for grain yield, $42.4,31.3$ and $26.3 \%$ for plant height, 17.8, 55.6 and $26.6 \%$ for test weight, 18.1, 17.7 and $64.2 \%$ for thousand grain weight, $25.0,10.9$ and $64.1 \%$ for screening percentages, 14.6, 79.4 and $6.0 \%$ for groat percentage content, 16.8, 56.0 and 27.2\% for ash, $4.2,88.2$ and $7.6 \%$ for protein content, $10.9,80.1$ and $9.0 \%$ for $\beta$-glucan content, $10.1,65.8$ and $24.1 \%$ for starch content were attributable to genotype, environment and GEI effects, respectively (Table 3).

Among the agronomic traits, grain yield has the most complex heredity and it is quite hard to achieve genetic progress in this issue. To measure the yield potential of a genotype, it should be experimented in more than one location with different climate and soil characteristics and/or in more than one year. Genotype yields varied between 1.97 (G22) - 4.06 (G7) ton ha ${ }^{-1}$ with an average value of 3.24 ton $\mathrm{ha}^{-1}$ (Table 4). The means for grain yield ranged from 2.21 ton ha ${ }^{-1}$ in environment E2 to 4.43 ton $\mathrm{ha}^{-1}$ in environment E5 (Table 5). In E5 and E6 environments with high grain yields, total precipitation and average temperature throughout the growing season were greater than the other environments. Such a case indicated that differences in genotypes, environments and genotype $\mathrm{x}$ environment interactions were mostly resulted from differences in soil characteristics, precipitation and temperature-like environmental factors (Table 2) and differences between the genotypes. Besides genetic factors, biotic and abiotic stress factors also result in different reactions of the genotypes to different environments. Low or high precipitations, high or low temperatures also influence interactions. Previous studies were reported that genotypes (Peterson et al. 2005; Mut et al. 2018), environmental factors (Doehlert et al. 2001) and agronomic practices (Finnan et al. 2019) were effective on grain yield.

There were significant differences in plant heights indicating a large genetic variation between the genotypes in all environments (Table 3). Plant height varied between $68.20 \mathrm{~cm}$ (G19) $-108.91 \mathrm{~cm}$ (G24) with an average value of $84.03 \mathrm{~cm}$. Significant differences were also observed in plant heights of the environments (Table 4). The highest plant height was observed in E5 environment $(93.31 \mathrm{~cm})$ and the lowest plant height was seen in E2 environment $(73.35 \mathrm{~cm})($ Table 5). Plant heights are largely influenced by water, temperature, nutrients, day light-like environmental factors (Coffman \& Frey 1961) and plant genetics (Buerstmayr et al. 2007). In present study, plant heights generally varied based on total precipitations (Table 2). Oat is also a desirable feature, as short plant heights and resistance to lodging attributes facilitate harvest processes (Erbaş Köse et al. 2021).

According to combined variance analysis, test weights of the genotypes varied between $40.99 \mathrm{~kg}(\mathrm{G} 24)$ and $48.84 \mathrm{~kg}(\mathrm{G} 5)$ (Table 4). The lowest test weight was observed in E6 environment (43.28 kg) and the greatest in E3 environment (50.39 $\mathrm{kg}$ ) (Table 5). Test weights generally vary with the genotypes, environmental conditions and cultural practices (Mut at al. 2018). High temperatures, drought or location-induced environmental stress reduce test weights of the cereals (Mut et al. 2018). In present study, E5 and E6 environments with greater average temperatures (Table 2) had lower test weights. Test weight designates the quality of oat grains, thus designate market price of oat. It is also used to identify quantity of grains damaged by adverse environmental conditions, diseases or cultural practices. Since greater test weights indicate greater groats percentages and less hull ratios, breeders generally try to select the genotypes with high test weights (Doehlert 2002). Because of high hull ratio and grain shape, oat generally has lower test weights than the other cereals and values vary between $40-60 \mathrm{~kg}$. In previous studies, test weights of oat genotypes were reported as between 40.3 to $55.6 \mathrm{~kg}$ (Mut et al. 2018). 
Table 4- ASV and GSI values for grain yield of 25 oat genotypes grown in different environments and average values of all characteristics of the genotypes studied in these environments

\begin{tabular}{|c|c|c|c|c|c|c|c|c|c|c|c|c|c|}
\hline \multirow[t]{2}{*}{ Genotypes } & \multicolumn{5}{|c|}{$G Y$} & \multirow{2}{*}{$\begin{array}{l}P H \\
(\mathrm{~cm})\end{array}$} & \multirow{2}{*}{$\begin{array}{l}T W \\
(\mathrm{~kg})\end{array}$} & \multirow{2}{*}{$\begin{array}{l}\text { TGW } \\
\text { (g) }\end{array}$} & \multirow{2}{*}{$\begin{array}{l}S P \\
(\%)\end{array}$} & \multirow{2}{*}{$\begin{array}{l}G P \\
(\%)\end{array}$} & \multirow{2}{*}{$\begin{array}{l}P C \\
(\%)\end{array}$} & \multirow{2}{*}{$\begin{array}{l}\beta C \\
(\%)\end{array}$} & \multirow{2}{*}{$\begin{array}{l}S C \\
(\%)\end{array}$} \\
\hline & $\begin{array}{l}\text { Mean } \\
\left(\mathrm{t} \mathrm{ha}^{-1}\right)\end{array}$ & $R G Y$ & $A S V$ & $R A$ & GSI & & & & & & & & \\
\hline G1 & $4.03^{\mathrm{ab}}$ & 2 & 0.52 & 14 & 16 & $81.22^{\mathrm{cd}}$ & $47.96^{\mathrm{a}}$ & $28.70^{\mathrm{i}}$ & $85.67^{\mathrm{c}-\mathrm{g}}$ & $75.42^{\mathrm{b}-\mathrm{g}}$ & $12.28^{\mathrm{ab}}$ & $3.72^{\mathrm{f}}$ & $45.46^{\mathrm{a}-\mathrm{e}}$ \\
\hline G2 & $3.69^{\mathrm{bcd}}$ & 6 & 0.91 & 19 & 25 & $81.52^{\mathrm{cd}}$ & $47.16^{\mathrm{ab}}$ & $28.89^{i}$ & $87.05^{\mathrm{bcd}}$ & $75.58^{\mathrm{a}-\mathrm{f}}$ & $11.20^{\mathrm{fg}}$ & $4.00^{\mathrm{a}-\mathrm{f}}$ & $44.65^{\mathrm{b}-\mathrm{g}}$ \\
\hline G3 & $3.77^{\mathrm{abc}}$ & 3 & 0.73 & 15 & 18 & $76.51^{\mathrm{de}}$ & $48.36^{\mathrm{a}}$ & $36.28^{\mathrm{ab}}$ & $89.48^{\mathrm{ab}}$ & $75.14^{\mathrm{b}-\mathrm{g}}$ & $11.74^{\mathrm{b}-\mathrm{f}}$ & $3.93^{\mathrm{b}-\mathrm{f}}$ & $46.77^{a b c}$ \\
\hline G4 & $3.70^{\mathrm{bcd}}$ & 5 & 0.51 & 12 & 17 & $79.39^{\mathrm{cd}}$ & $48.75^{\mathrm{a}}$ & $35.92^{\mathrm{abc}}$ & $86.09^{\text {cde }}$ & $73.62^{\mathrm{ghi}}$ & $11.93^{\mathrm{b}-\mathrm{e}}$ & $4.08^{\mathrm{a}-\mathrm{d}}$ & $44.43^{\mathrm{c}-\mathrm{g}}$ \\
\hline G5 & $2.66^{\mathrm{jkl}}$ & 21 & 0.38 & 7 & 28 & $80.59^{\mathrm{cd}}$ & $48.84^{\mathrm{a}}$ & $31.23^{\mathrm{ghi}}$ & $82.93^{\mathrm{gh}}$ & $75.07^{\mathrm{b}-\mathrm{g}}$ & $12.17^{\mathrm{abc}}$ & $3.99^{\mathrm{a}-\mathrm{f}}$ & $46.98^{\mathrm{ab}}$ \\
\hline G6 & $3.59^{\text {cde }}$ & 8 & 0.47 & 9 & 17 & $85.78^{\mathrm{bc}}$ & $47.35^{\mathrm{ab}}$ & $32.22^{\mathrm{e}-\mathrm{h}}$ & $83.66^{\mathrm{efg}}$ & $72.86^{\mathrm{hi}}$ & $11.86^{\mathrm{b}-\mathrm{e}}$ & $3.89^{\mathrm{b}-\mathrm{f}}$ & $44.15^{\mathrm{d}-\mathrm{g}}$ \\
\hline G7 & $4.06^{\mathrm{a}}$ & 1 & 0.90 & 18 & 19 & $80.14^{\mathrm{cd}}$ & $47.86^{\mathrm{a}}$ & $33.01^{\mathrm{c}-\mathrm{h}}$ & $79.85^{\mathrm{ij}}$ & $75.88^{\mathrm{a}-\mathrm{e}}$ & $12.27^{\mathrm{ab}}$ & $4.12^{\mathrm{abc}}$ & $43.32^{\mathrm{e}-\mathrm{h}}$ \\
\hline G8 & $3.22^{\mathrm{f}-\mathrm{i}}$ & 14 & 0.51 & 11 & 25 & $91.05^{\mathrm{b}}$ & $47.14^{\mathrm{ab}}$ & $35.55^{\mathrm{a}-\mathrm{d}}$ & $84.86^{\mathrm{d}-\mathrm{g}}$ & $74.81^{\mathrm{b}-\mathrm{g}}$ & $11.88^{\mathrm{b}-\mathrm{e}}$ & $3.93^{b-f}$ & $43.46^{\mathrm{e}-\mathrm{h}}$ \\
\hline G9 & $3.15^{\mathrm{ghi}}$ & 15 & 0.90 & 17 & 32 & $80.44^{\mathrm{cd}}$ & $46.75^{\mathrm{ab}}$ & $33.12^{\mathrm{c}-\mathrm{h}}$ & $82.91^{\mathrm{gh}}$ & $73.95^{\mathrm{f}-\mathrm{i}}$ & $12.04^{\mathrm{a}-\mathrm{d}}$ & $3.85^{\mathrm{c}-\mathrm{f}}$ & $44.93^{\mathrm{a}-\mathrm{f}}$ \\
\hline G10 & $3.09^{\text {ghi }}$ & 16 & 0.88 & 16 & 32 & $76.55^{\mathrm{de}}$ & $47.69^{\mathrm{ab}}$ & $32.65^{\mathrm{d}-\mathrm{h}}$ & $83.50^{\mathrm{e}-\mathrm{g}}$ & $75.13^{\mathrm{b}-\mathrm{g}}$ & $11.49^{\mathrm{d}-\mathrm{g}}$ & $4.17^{\mathrm{ab}}$ & $45.11^{\mathrm{a}-\mathrm{f}}$ \\
\hline G11 & $3.01^{\text {hij }}$ & 19 & 0.52 & 13 & 32 & $85.92^{\mathrm{bc}}$ & $47.38^{\mathrm{ab}}$ & $35.21^{\mathrm{a}-\mathrm{e}}$ & $85.86^{\mathrm{c}-\mathrm{f}}$ & $76.73^{\mathrm{ab}}$ & $12.04^{\mathrm{a}-\mathrm{d}}$ & $4.26^{\mathrm{a}}$ & $45.25^{\mathrm{a}-\mathrm{f}}$ \\
\hline G12 & $3.29^{\mathrm{e}-\mathrm{h}}$ & 13 & 0.94 & 20 & 33 & $71.01^{\mathrm{ef}}$ & $48.30^{\mathrm{a}}$ & $30.20^{\mathrm{hi}}$ & $83.17^{\mathrm{fgh}}$ & $72.64^{\mathrm{i}}$ & $12.12^{\mathrm{abc}}$ & $4.01^{\mathrm{a}-\mathrm{e}}$ & $43.51^{\mathrm{e}-\mathrm{h}}$ \\
\hline G13 & $3.05^{\mathrm{hi}}$ & 18 & 0.29 & 4 & 22 & $84.94^{\mathrm{bc}}$ & $47.54^{\mathrm{ab}}$ & $33.68^{\mathrm{a}-\mathrm{g}}$ & $85.93^{c-f}$ & $75.63^{\mathrm{a}-\mathrm{f}}$ & $11.74^{\mathrm{b}-\mathrm{f}}$ & $4.00^{\mathrm{a}-\mathrm{f}}$ & $43.72^{\mathrm{e}-\mathrm{h}}$ \\
\hline G14 & $3.59^{\text {cde }}$ & 9 & 0.42 & 8 & 17 & $85.55^{\mathrm{bc}}$ & $48.27^{\mathrm{a}}$ & $31.79^{\mathrm{f}-\mathrm{i}}$ & $89.35^{\mathrm{ab}}$ & $74.60^{\mathrm{c}-\mathrm{h}}$ & $12.18^{\mathrm{abc}}$ & $4.11^{\mathrm{abc}}$ & $45.20^{\mathrm{a}-\mathrm{f}}$ \\
\hline G15 & $3.56^{\mathrm{c}-\mathrm{f}}$ & 10 & 1.22 & 22 & 32 & $88.55^{\mathrm{b}}$ & $48.13^{\mathrm{a}}$ & $34.08^{\mathrm{a}-\mathrm{g}}$ & $85.05^{\mathrm{d}-\mathrm{g}}$ & $77.26^{\mathrm{a}}$ & $11.64^{\mathrm{c}-\mathrm{f}}$ & $3.82^{\mathrm{def}}$ & $46.44^{\mathrm{a}-\mathrm{d}}$ \\
\hline G16 & $3.71^{\mathrm{abc}}$ & 4 & 1.40 & 24 & 28 & $86.16^{\mathrm{bc}}$ & $47.03^{\mathrm{ab}}$ & $32.10^{\mathrm{e}-\mathrm{h}}$ & $84.92^{\mathrm{d}-\mathrm{g}}$ & $76.36^{\mathrm{abc}}$ & $11.50^{\mathrm{d}-\mathrm{g}}$ & $3.79^{\mathrm{ef}}$ & $44.46^{\mathrm{c}-\mathrm{g}}$ \\
\hline G17 & $2.42^{1}$ & 23 & 0.50 & 10 & 33 & $80.73^{\mathrm{cd}}$ & $46.81^{\mathrm{ab}}$ & $35.71^{\mathrm{a}-\mathrm{d}}$ & $88.23^{\mathrm{bc}}$ & $74.38^{\mathrm{d}-\mathrm{i}}$ & $11.80^{\mathrm{b}-\mathrm{e}}$ & $4.11^{\mathrm{abc}}$ & $42.30^{\text {gh }}$ \\
\hline G18 & $3.43^{\mathrm{c}-\mathrm{g}}$ & 11 & 0.14 & 2 & 13 & $75.05^{\mathrm{def}}$ & $46.98^{\mathrm{ab}}$ & $34.13^{\mathrm{a}-\mathrm{g}}$ & $86.13^{\text {cde }}$ & $76.24^{\mathrm{a}-\mathrm{d}}$ & $11.66^{\mathrm{c}-\mathrm{f}}$ & $4.01^{\mathrm{a}-\mathrm{e}}$ & $45.14^{\mathrm{a}-\mathrm{f}}$ \\
\hline G19 & $3.36^{\mathrm{d}-\mathrm{h}}$ & 12 & 0.35 & 6 & 18 & $68.20^{\mathrm{f}}$ & $46.96^{\mathrm{ab}}$ & $34.40^{\mathrm{a}-\mathrm{f}}$ & $84.58^{\mathrm{d}-\mathrm{g}}$ & $74.17^{\mathrm{e}-\mathrm{i}}$ & $11.90^{\mathrm{b}-\mathrm{e}}$ & $4.04^{\mathrm{a}-\mathrm{e}}$ & $43.65^{\mathrm{e}-\mathrm{h}}$ \\
\hline G20 & $2.88^{\mathrm{ijk}}$ & 20 & 0.11 & 1 & 21 & $76.89^{\mathrm{de}}$ & $47.10^{\mathrm{ab}}$ & $33.24^{\mathrm{b}-\mathrm{h}}$ & $86.12^{\text {cde }}$ & $76.08^{\mathrm{a}-\mathrm{e}}$ & $11.84^{\mathrm{b}-\mathrm{e}}$ & $3.98^{\mathrm{a}-\mathrm{f}}$ & $47.42^{\mathrm{a}}$ \\
\hline G21 & $3.07^{\mathrm{hi}}$ & 17 & 0.33 & 5 & 22 & $89.12^{\mathrm{b}}$ & $46.87^{\mathrm{ab}}$ & $34.53^{\mathrm{a}-\mathrm{f}}$ & $80.81^{\mathrm{hi}}$ & $75.14^{\mathrm{b}-\mathrm{g}}$ & $12.53^{\mathrm{a}}$ & $4.16^{\mathrm{ab}}$ & $42.91^{\mathrm{fgh}}$ \\
\hline G22 & $1.97^{\mathrm{m}}$ & 25 & 1.50 & 25 & 50 & $103.14^{\mathrm{a}}$ & $43.27^{\mathrm{cd}}$ & $30.15^{\mathrm{hi}}$ & $77.89^{j}$ & $75.50^{\mathrm{a}-\mathrm{g}}$ & $10.98^{\mathrm{g}}$ & $3.78^{\mathrm{ef}}$ & $41.45^{\mathrm{h}}$ \\
\hline G23 & $2.59^{\mathrm{kl}}$ & 22 & 1.36 & 23 & 45 & $107.67^{a}$ & $45.14^{\mathrm{bc}}$ & $32.92^{\mathrm{c}-\mathrm{h}}$ & $79.20^{\mathrm{ij}}$ & $74.89^{\mathrm{b}-\mathrm{g}}$ & $11.65^{\mathrm{c}-\mathrm{f}}$ & $3.78^{\mathrm{ef}}$ & $44.77^{\mathrm{b}-\mathrm{g}}$ \\
\hline G24 & $2.41^{1}$ & 24 & 0.99 & 21 & 45 & $108.91^{\mathrm{a}}$ & $40.99^{d}$ & $34.33^{\mathrm{a}-\mathrm{g}}$ & $79.72^{\mathrm{ij}}$ & $74.42^{\mathrm{d}-\mathrm{i}}$ & $11.40^{\text {efg }}$ & $4.01^{\mathrm{a}-\mathrm{e}}$ & $44.99^{\mathrm{a}-\mathrm{f}}$ \\
\hline G25 & $3.69^{\mathrm{bcd}}$ & 7 & 0.14 & 3 & 10 & $75.76^{\mathrm{de}}$ & $48.36^{\mathrm{a}}$ & $36.72^{\mathrm{a}}$ & $91.94^{\mathrm{a}}$ & $77.09^{\mathrm{a}}$ & $12.23^{\mathrm{abc}}$ & $4.00^{\mathrm{a}-\mathrm{f}}$ & $46.81^{\mathrm{abc}}$ \\
\hline
\end{tabular}

The values followed by common letters at each column are not significant at P>0.05 level of probability using the Tukeys test. GY: Grain yield; ASV: AMMI stability values; GSI: Genotype selection index; PH: Plant height; TW: Test weight; TGW: Thousand-grain weight; SP: Screenings percentage; GP: Groat percentage; PC: Protein content; $\beta C$ : $\beta$-glucan content; SC: Starch content

Although thousand-grain weight is a cultivar-specific trait, it varies with the years and climate factors. In present study, thousand-grain weights of the genotypes varied between 28.70 (G1) and $36.72 \mathrm{~g}(\mathrm{G} 25)$ with an average value of $33.23 \mathrm{~g}$. The means for thousand-grain weight ranged from $30.75 \mathrm{~g}$ in environment E3 to $35.56 \mathrm{~g}$ in environment E5 (Table 4). Genotype $\mathrm{x}$ environment interactions was found to be significant for thousand-grain weight. It was thought that greater precipitation and temperatures of E4, E5 and E6 environments than of E1, E2 and E3 environments (Table 2) positively influenced oat growth and thousand-grain weight. Peterson (1992) reported greater impacts of environment on thousand-grain weights than on the other quality traits. In previous studies, thousand-grain weights of oat genotypes were reported as between $18.55-47.11 \mathrm{~g}$ (Buerstmayr et al. 2007; Mut et al. 2018; Mut et al. 2021).

Based on combined results of the environments, screening percentage of the genotypes varied between 77.89 (G22) and $91.94 \%$ (G25) with an average value of $84.60 \%$ (Table 4). The greatest screening percentage was observed in E6 environment $(88.12 \%)$ and the lowest value in E3 environment (81.70\%) (Table 5). Because of differences in panicle lengths and number of grains per spikelet, oat grains generally have different sizes (Doehlert 2002). Screening percentage is influenced by environmental factors as much as genotypes. Screening percentages are closely related to grain size and the genotypes with greater thousand-grain weights also have greater screening percentages (Kahraman et al. 2017). Grain size generally designates the purpose of use in oat grains. Homogeneous grain size is preferred in flour industry. Hulls should be removed in oat meals. Therefore, larger grains are preferred as to have greater groats percentages. Small grains generally fractured while dehulling process and such a case then reduces milling performance. Thus, oat grains are size-classified in milling industry and very small and weak grains are generally used in animal feeding (Doehlert 2002). Screening percentages of hulled-oat genotypes were reported as between $17.3-95.5 \%$ by Kahraman et al. (2017). 
Table 5- Average values of the investigated properties of the environments

\begin{tabular}{|c|c|c|c|c|c|c|c|c|c|c|c|c|c|}
\hline \multirow[b]{2}{*}{ Env. } & \multicolumn{5}{|c|}{$G Y$} & \multirow{2}{*}{$\begin{array}{l}P H \\
(\mathrm{~cm})\end{array}$} & \multirow{2}{*}{$\begin{array}{l}T W \\
(\mathrm{~kg})\end{array}$} & \multirow{2}{*}{$\begin{array}{l}T G W \\
(\mathrm{~g})\end{array}$} & \multirow{2}{*}{$\begin{array}{l}S P \\
(\%)\end{array}$} & \multirow{2}{*}{$\begin{array}{l}G P \\
(\%)\end{array}$} & \multirow{2}{*}{$\begin{array}{l}P C \\
(\%)\end{array}$} & \multirow{2}{*}{$\begin{array}{l}\beta C \\
(\%)\end{array}$} & \multirow{2}{*}{$\begin{array}{l}S C \\
(\%)\end{array}$} \\
\hline & $\begin{array}{l}\text { Mean } \\
\left(\mathrm{t} \mathrm{ha}^{-1}\right)\end{array}$ & $R G Y$ & $A S V$ & $R A$ & GSI & & & & & & & & \\
\hline E1 & $3.16^{\mathrm{c}}$ & 3 & 1.27 & 2 & 5 & $81.59^{c}$ & $46.85^{\mathrm{c}}$ & $31.71^{\mathrm{cd}}$ & $85.52^{b}$ & $70.62^{d}$ & $12.44^{\mathrm{b}}$ & $4.22^{b}$ & $40.33^{\mathrm{e}}$ \\
\hline $\mathrm{E} 2$ & $2.21^{\mathrm{f}}$ & 6 & 1.10 & 1 & 7 & $73.35^{\mathrm{d}}$ & $49.27^{b}$ & $32.77^{c}$ & $84.05^{b}$ & $76.50^{\mathrm{b}}$ & $13.84^{\mathrm{a}}$ & $3.99^{c}$ & $42.70^{\mathrm{d}}$ \\
\hline E3 & $2.94_{d}$ & 4 & 1.33 & 3 & 7 & $75.10^{d}$ & $50.39^{a}$ & $30.75^{d}$ & $81.70^{c}$ & $75.92^{\mathrm{b}}$ & $12.31^{\mathrm{b}}$ & $3.95^{\mathrm{c}}$ & $45.00^{c}$ \\
\hline E4 & $2.75^{\mathrm{e}}$ & 5 & 1.46 & 4 & 9 & $90.19^{b}$ & $47.64_{c}$ & $34.25^{\mathrm{b}}$ & $84.17^{b}$ & $77.91^{\mathrm{a}}$ & $11.96^{\mathrm{c}}$ & $3.64^{\mathrm{d}}$ & $49.27^{\mathrm{a}}$ \\
\hline E5 & $4.43^{\mathrm{a}}$ & 1 & 2.35 & 6 & 7 & $93.31^{\mathrm{a}}$ & $45.05^{\mathrm{d}}$ & $35.56^{\mathrm{a}}$ & $85.00^{\mathrm{b}}$ & $75.78^{b}$ & $10.48^{d}$ & $3.63^{\mathrm{d}}$ & $46.43^{b}$ \\
\hline E6 & $3.94^{\mathrm{b}}$ & 2 & 1.77 & 5 & 7 & $90.15^{b}$ & $43.28^{\mathrm{e}}$ & $34.33^{\mathrm{b}}$ & $88.12^{\mathrm{a}}$ & $74.10^{c}$ & $10.02^{\mathrm{e}}$ & $4.46^{\mathrm{a}}$ & $44.42^{\mathrm{c}}$ \\
\hline Mean & 3.24 & & & & & 84.03 & 47.08 & 33.23 & 84.60 & 75.14 & 11.84 & 3.98 & 44.69 \\
\hline
\end{tabular}

The values followed by common letters at each column are not significant at P>0.05 level of probability. The values followed by common letters at each column are not significant at P>0.05 level of probability using the Tukeys test. GY: Grain yield; ASV: AMMI stability values; GSI: Genotype selection index; PH: Plant height; TW: Test weight; TGW: Thousand-grain weight; SP: Screenings percentage; GP: Groat percentage; PC: Protein content; $\beta C$ : $\beta$-glucan content; SC: Starch content

Oat groats (caryopsis) are covered with the hull at harvest. Such grains should be dehulled to use in food industry. Groat percentage of the genotypes varied between 72.64 (G12) and 77.26\% (G15) with a general average of 75.14\% (Table 4). The lowest groat percentage was observed in E1 environment (70.62\%) and the greatest value in E4 environment (77.91\%) (Table 5). Buerstmayr et al. (2007) indicated that environment had greater effects on groat percentage than the genotypes. Doehlert et al. (2001) indicated almost identical effects of genotype and environment on groat percentage. Groat percentage could be increased by $>10 \%$ by selecting an appropriate growing site. Groat percentage is an important quality indicator of oat grains. Greater hull ratios limit the use of oat grains in animal feeding. Also, greater groat percentage and lower hull ratios are desired for oat grains to be used in human nutrition. Groat percentage of oat genotypes was reported as between $63.7-91.7 \%$ by Doehlert et al. (2001) and between $70.1-73.6 \%$ by Mut et al. (2018).

Protein content of oat grains is an important quality parameter. Protein contents of the genotypes varied between 10.98 (G22) and $12.53 \%$ (G21) with a general average of $11.84 \%$ (Table 4). Peterson et al. (2005) reported protein content of oat genotypes as between 10.0 - 18.0\%. Significant differences were reported in protein content of different oat genotypes (Mut et al. 2018). In this study, the means for protein content ranged from $10.02 \%$ in environment E6 to $13.84 \%$ in environment E2 (Table 5). Acar et al. (1995) and Peterson et al. (2005) indicated that although protein contents were largely depended on genotypes, it was also largely influenced by environment. Mut et al. (2018) reported that protein contents were influenced both by environment and genotypes. Similar to the results obtained in this study, Peltonen-Sainio \& Peltonen (1993) reported that the differences in protein content of genotypes could be attributed to the reduction in starch accumulation as a result of the troubles occurring in the grain filling period. According to tested environments, decreasing protein contents were observed (Table 5) with increasing precipitations of the environments (Table 2). Dryer vegetation periods in E1, E2 and E3 environments resulted in reduced grain weight and increased crude protein contents.

The $\beta$-glucan is an important naturally dissolving dietary fiber and oat grains are quite rich in $\beta$-glucan. $\beta$-glucan contents of the genotypes varied between $3.72(\mathrm{G} 1)$ and $4.26 \%(\mathrm{G} 11)$ with a general average of $3.98 \%$ (Table 4$)$. For $\beta$-glucan contents of the environments, the greatest value was observed in E6 environment $(4.46 \%)$ and the lowest value in E5 environment $(3.63 \%)$ (Table 5). It was reported that $\beta$-glucan boosted the immune system, reduced blood cholesterol and glucose levels (Peterson et al. 2005). $\beta$-glucans are also used in cosmetics, food and pharmaceutical industries. High $\beta$-glucan contents are desired in oat grains to be used in human nutrition and animal feeding. It was reported in previous studies that $\beta$-glucan contents were influenced by genotypes (Doehlert et al. 2001; Mut et al. 2017) environments and cultural practices (Mut et al. 2018).

Based on combined results of the environments, starch contents of the genotypes varied between 41.45 (G22) and $47.42 \%$ (G20) with a general average of $44.69 \%$. The means for starch content ranged from $40.33 \%$ in environment E1 to $49.27 \%$ in environment E4. Starch is composed of amylose and amylopectin and starch of oat grain is located in endosperm covered with bran layers rich in $\beta$-glucan and protein (Punia et al. 2020). Starch is the primary digestible carbohydrate of the plants, thus offers important source energy in human nutrition and animal feeding. In this study, greater starch contents were observed in environments with greater total precipitations (Table 2, 4 and 5). Doehlert et al. (2001) indicated highly significant effects of environments on starch contents. Mut et al. (2018) indicated that starch contents were influenced both by environment and genotypes and reported starch contents of oat genotypes as between $42.7-49.6 \%$.

AMMI analysis for the grain yield indicated variation among $\mathrm{E}, \mathrm{G}$ and $\mathrm{G} \times \mathrm{E}$ showed highly significant different at level $\mathrm{P}<$ 0.01 , indicating the existence of differential responses of genotypes to different environments (Table 6). In the analysis of variance, the sum of squares for environment main effect accounted for $51.3 \%$ of the general sum. The differences between genotypes explained $16.7 \%$ of the total variation, while the effects of GE interaction explained $32.0 \%$. 
Table 6- AMMI analysis for grain yield of 25 genotypes evaluated in 6 environments

\begin{tabular}{llllll}
\hline Source & $D F$ & $S S$ & $M S$ & F Ratio & Explained (\%) \\
\hline Model & 152 & 711.00 & 4.67 & $38.75^{* *}$ & \\
Environment & 5 & 334.15 & 66.83 & $553.57^{* *}$ & 51.3 \\
Genotypes & 24 & 163.92 & 6.82 & $56.57^{* *}$ & 16.7 \\
G $\times$ E & 120 & 209.98 & 1.74 & $14.49^{* *}$ & 32.0 \\
IPCA 1 & 28 & 97.75 & 3.49 & $28.92^{* *}$ & 46.55 \\
IPCA 2 & 26 & 38.53 & 1.52 & $12.59^{* *}$ & 18.82 \\
IPCA 3 & 24 & 34.90 & 1.45 & $12.05^{* *}$ & 16.62 \\
IPCA 4 & 22 & 22.47 & 1.02 & $8.47^{* *}$ & 10.71 \\
IPCA 5 & 20 & 15.32 & 0.77 & $6.34^{* *}$ & 7.29 \\
Pooled error & 447 & 53.96 & 0.12 & & \\
Total & 599 & 794.67 & & &
\end{tabular}

Results of AMMI analysis showed that the first five interaction principal component axes (IPCA) for grain yield were highly significant $(\mathrm{P}<0.01)$. IPCA1, IPCA2, IPCA3, IPCA4 and IPCA5 respectively explained for 46.55\%, 18.82\%, 16.62\%, $10.71 \%$, and $7.29 \%$ of the variation formed by interaction (Table 6). The AMMI with IPCA1 and IPCA2 is the best predictive model for to explain interpretable patterns of the yield variation explained by the GEI (Gauch \& Zobel 1996). The model was adequate enough to explain the total GEI component (Yan \& Tinker 2006). In Figure 1A shows the stability of genotypes and environments, as well as association between genotypes and environments (Gauch and Zobel 1996). G16, G15, G12, G19, G7, G18, G3, G1, G6, G25, G14, G4 and G2 had above mean grain yield in the favourable environments, while G9, G10, G21, G5, G20, G8, G13, G11, G24 and G23 were below the average grain yield in the unfavourable environments. When environments suitability are also classified according their position found in the quadrant, E5 and E6 were favourable environments while E1, E2, E3, E4 and E7 were considered as unfavourable environments for grain yield (Figure 1A). Genotype stability is considered as non-significant response to changing environmental conditions, agricultural practices, climate conditions, multiple stresses. In this study, weather conditions were the source of this variation component.

According to AMMI stability value (ASV), genotypes with lower ASV values are considered more stable than the genotypes with higher ASV (Purchase et al. 2000). According to this model, G18, G20 and G25 were the most stable while G22 were the most unstable. In terms of environments, the smallest ASV values were E2, E1, E3, E4, E6 and E5, respectively (Table 5). The GSI, which incorporates both stability and yield, pointed out G25, G18, G1, G4, G6, G7, G14, G3 and G19 as the best genotypes (Table 4).

Biplot graph (Figure 1B and 1C) offer visual assessment of the relationships among the traits, to define positive or negative relationships among the investigated traits and to define traits to be used in indirect selection of another trait. Biplot graph also presents strong and weak traits of the genotypes (Yan \& Tinker 2006). The length of an environmental vector is a forecast of discriminating power of the environment (Yan et al. 2016). In this study, the environments E6, E3 and E1 largely contributed to the $\mathrm{G} \times \mathrm{E}$ interaction. With the longest vectors from the origin, environment E6 was the most discriminating of the genotypes while E4 provided little information about the genotype differences. The genotypes G5, G14, G15 and G18 interacted positively with the E1 and E2 environments (Figure 1B). The genotypes G3, G12, G23, G24 and G25 interacted positively with the E3, E4 and E5 environments, but negatively with the E6. The genotypes G1, G2, G6, G17, G19 and G21 interacted positively with the E6 environment.

According to Figure 1C, multivariate relationships between the environments and investigated traits of 25 oat genotypes were assessed through PCA. And then PC1 and PC2 values were compared to generate biplot graphs (Figure 1C). PC1 explained $38.2 \%$ and PC2 explained $16.7 \%$ of total variation. These two components constituted more than half of total variation (54.9\%). In biplot graph, vector angles of less than $90^{\circ}$ indicate genotype performance of higher than the average, vector angles greater than $90^{\circ}$ indicate genotype performance of lower than the average and finally vector angles equal or close to $90^{\circ}$ indicate genotype performance of close to average (Yan \& Tinker 2006). For 25 oat genotypes, grain yield had positive correlations with all characteristics except plant height $\left(<90^{\circ}\right)$. The G25 cultivar had greater than the general average in terms of all traits except plant height. The G22, G23 and G24 genotypes had the greatest plant heights. The genotypes positioned closer to the center were prominent for more than one trait and generally averages were lower than the values of genotypes prominent for a single trait (Figure 1C). Similar with the present findings, Yan et al. (2016) reported positive relationships between grain yield and $\beta$-glucan content while they reported negative correlations between $\beta$-glucan and groat percentage. Buerstmayr et al. (2007) showed that the positive association of grain yield with thousand kernel weight and screenings percentage. 

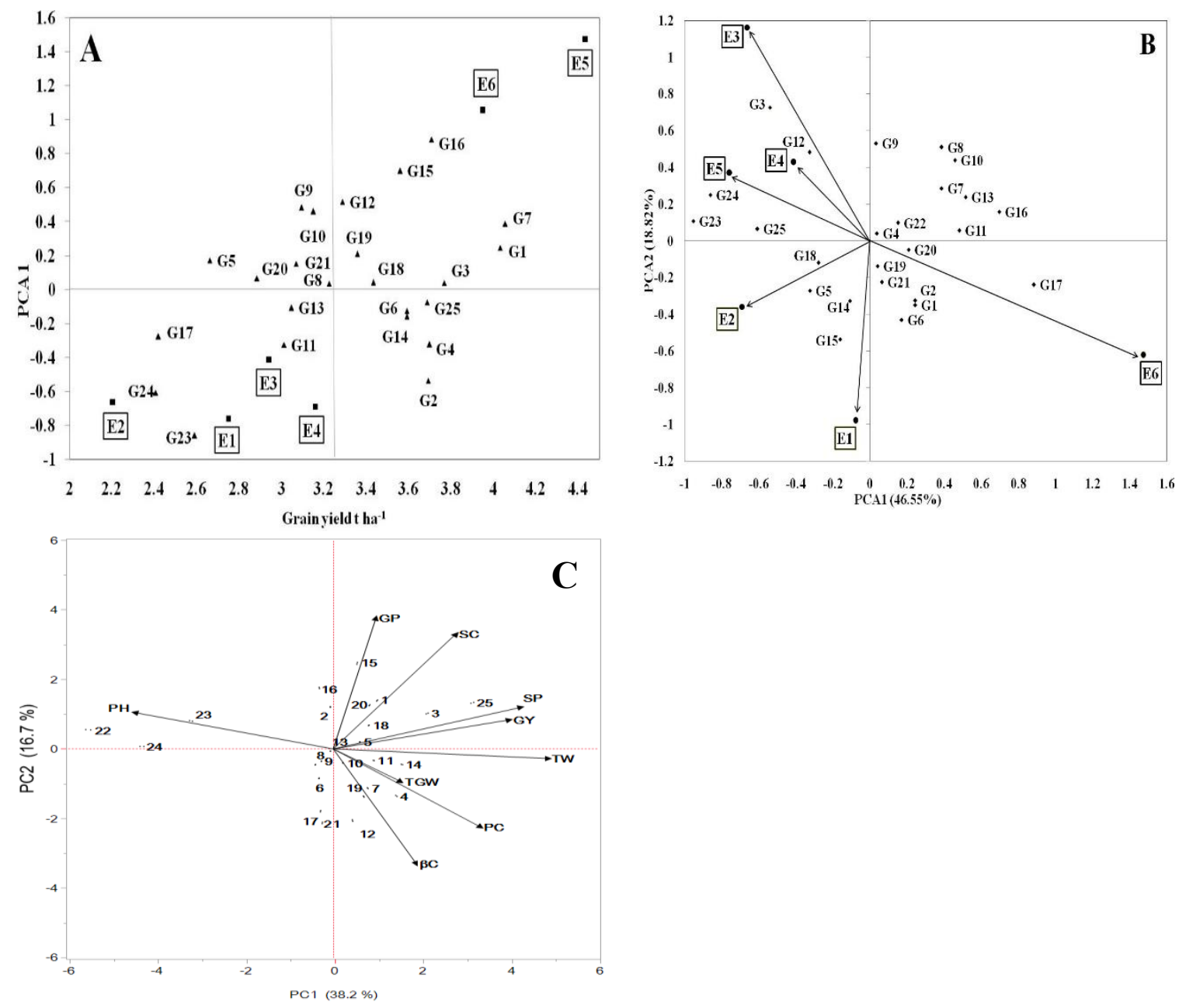

Figure 1- The AMMI model based on grain yield of genotypes (G) in 6 environments (E) (A), Biplot analysis of GEI based on AMMI 2 model for the first two interactions principal component scores $(B)$, Genotype $\times$ Trait biplot for investigated traits of oat genotypes $(\mathrm{C})$

\section{Conclusions}

In this study, grain yield and quality traits were significantly influenced by genotype, environment and their interactions. Based on genotype selection index (GSI), G25, G18, G1, G4, G6, G7, G14, G3 and G19 were considered as most stable genotypes. The G1, G3 and G7 numbered advanced lines among these genotypes had higher yields than standard cultivars (G24 and G25). In addition, these genotypes showed above average values for most of the quality traits. These advanced lines could be advised for wider growing environments. In addition, these genotypes as parents can be used in oat breeding programs.

\section{Acknowledgements}

This text has been proofread and edited by the Prof. Zeki GÖKALP.

\section{References}

AACC (2000). Approved Methods of American Association of Cereal Chemists. 10 ${ }^{\text {th }}$ Ed. American Association of Cereal Chemists, Minnesota, USA.

Acar Z, Ayan I Korkmaz A \& Gülser C (1995). Mineral composition of the grains obtained from different oat varieties grown in Samsun province. OMU Journal of the Faculty of Agriculture 10(3):95-104

Anonymous (2016). Turkish State Meteorological Service. Available at [Access date: 13.12.2016]. https://mgm.gov.tr/eng/forecastcities.aspx

Buerstmayr H, Krenn N, Stephan U, Grausgruber H \& Zechner E (2007). Agronomic performance and quality of oat (Avena sativa L.) genotypes of worldwide origin produced under central European growing conditions. Field Crops Research 101: 343-351. doi: 10.1016/j.fcr.2006.12.011

Coffman F A \& Frey K J (1961). Influence of climate and physiologic factors on growth in oats. In Coffman FL (Ed). Oats and oat improvement, John Wiley and Sons (pp. 420-464), US. doi: 10.2134/agronmonogr8.c12 
Crossu J (1990). Statistical analyses of multi-location trials. Advances in Agronomy 44: 55-85. doi: 10.1016/S0065-2113(08)60818-4

Doehlert DC (2002). Quality improvement in oat. Journal of crop production 5(1-2): 165-189. doi: 10.1300/J144v05n01_07

Doehlert DC, Mcmullen MS \& Hammond JJ (2001). Genotyping and environmental effects on grain yield and quality of oat grown in North Dakota. Crop Science 41: 1066-1072. doi: 10.2135/cropsci2001.4141066x

Erbaş Köse ÖD, Mut Z \& Akay H (2021). Assessment of grain yield and quality traits of diverse oat (Avena sativa L.) Genotypes. Annali Di Botanica, 11: 55-66. doi: 10.13133/2239-3129/16777

FAO - Food and Agriculture Organization of the United Nations (2018) FAOSTAT statistical database. FAO, Rome.

Farshadfar E \& Sutka J (2003). Locating QTLs controlling adaptation in wheat using AMMI model. Cereal Research Communication 3: 249256. doi: 10.1007/BF03543351

Finnan J, Burke BY \& Spink J (2019). The effect of nitrogen timing and rate on radiation interception, grain yield and grain quality in autumn sown oats. Field crops research 231:130-140. doi: 10.1016/j.fcr.2018.12.001

Gauch H G (1993). Matmodel version 2.0: AMMI and related analysis for two-way data matrices. Micro Computer Power, Ithaca, New York, USA.

Gauch H G \& Zobel R W (1996). AMMI Analysis of Yield Trials. In Kang MS and Gauch HG (Eds.). Genotype-by-Environment Interaction, Taylor and Francis (pp. 85-122), FL.

Kahraman T, Avci R \& Kurt T (2017). Determination of grain yield, quality and agronomic traits of some oat (Avena sativa L.) genotypes. Journal of Field Crops Central Research Institute 26: 74-79 (In Turkish).

Michels D K, Chatham L A, Butts-Gilmsmeyer C J, Juvik J A \& Kolb F L (2020). Variation in avenanthramide content in spring oat over multiple environments. Journal of Cereal Science 91: 102-886. doi: 10.1016/j.jcs.2019.102886

Blagojević M, Đorđević N, Bora D, Marković J, Vasić T, Milenković J \& Petrović M (2017). Determination of green forage and silage protein degradability of some pea (Pisum sativum L.) + oat (Avena sativa L.) mixtures grown in Serbia. Journal of Agricultural Sciences 23(4): 415-422. doi: 10.15832/ankutbd.385865

Mut Z, Erbaş Köse ÖD \& Akay H, (2017). Chemical quality properties of different oat (Avena sativa L.) cultivars. Yuzuncu Y11 University Journal of Agricultural Sciences 27 (3): 347-356. doi: 10.29133/yyutbd.290920

Mut Z, Akay H \& Erbaş Köse ÖD (2018). Grain yield, quality traits and grain yield stability of local oat cultivars. Journal of Soil Science and Plant Nutrition 18(1): 269-281. doi: 10.4067/S0718-95162018005001001.

Mut Z, Erbaş Köse ÖD, Akay H, Sezer, İ. (2021). Evaluation of some characteristics of local oat genotypes collected from the Central and Western Black Sea Region, Journal of the Institute of Science and Technology, 11(2): 1582-1594. Doi: 10.21597/jist.858573

Peltonen-Sainio P \& Peltonen J (1993). Stability of quality traits in spring cereals cultivated under the growing conditions of southern Finland. Acta Agriculturae Scandinavica B-Plant Soil Sciences 43(1): 45-52. doi: 10.1080/09064719309410231

Peterson DM (1992). Composition and nutritional characteristics of oat grain products. In Marshall HG and Sorrells ME (Eds) Oat Science and Technology, (p. 265-292), Madison: American Society of Agronomy. doi: 10.2134/agronmonogr33.c10

Peterson DM, Wesenberg D M, Burrup D E \& Erickson C A (2005). Relationships among agronomic traits and grain composition in oat genotypes grown in different environments. Crop Sciences 45: 1249-1255. doi: 10.2135/cropsci2004.0063

Punia S, Sandhu KS, Dhull SG, Siroha AK, Purewal SS, Kaur M \& Kidwai MK (2020). Oat starch: Physico-chemical, morphological, rheological characteristics and its application-A review. Inter. Journal of Biological Macromolecules 154: 493-498. Doi: 10.1016/j.ijbiomac.2020.03.083

Purchase JL, Hatting H \& Vandeventer CS (2000). Genotype $\times$ environment interaction of winter wheat (Triticum aestivum L.) in South Africa: П. Stability analysis of yield performance. South African Journal of Plant Soil 17: 101-107. doi: $10.1080 / 02571862.2000 .10634878$

Sánchez-Martín J, Rubiales D, Flores F, Emeran A A, Shtaya M J Y, Sillero J C \& Prats E (2014). Adaptation of oat (Avena sativa) cultivars to autumn sowings in Mediterranean environments. Field Crops Research 156: 111-122. doi: 10.1016/j.fcr.2013.10.018

SAS (1998). SAS proprietary software. Release 8.2. SAS Institute Cary, NC.

Yan W \& Tinker NA (2006). Biplot analysis of multi-environment trial data: Principles and applications. Canadian Journal of Plant Science 86: 623-645. doi: 10.4141/P05-169

Yan W, Frégeau-Reid J, Pageau D \& Martin R (2016). Genotype-by-environment interaction and trait associations in two genetic populations of oat. Crop Science 56(3): 1136-1145. doi: 10.2135/cropsci2015.11.0678

Zobel RW, Wright MS \& Gauch HG (1988). Statistical analysis of a yield trial. Agronomy Journal 80: 388-393. doi: 10.2134/agronj1988.00021962008000030002x

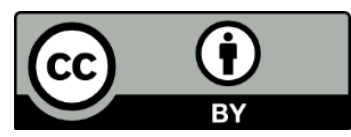

(C) 2022 by the author(s). Published by Ankara University, Faculty of Agriculture, Ankara, Turkey. This is an Open Access article distributed under the terms and conditions of the Creative Commons Attribution (CC BY) license (http://creativecommons.org/licenses/by/4.0/), which permits unrestricted use, distribution, and reproduction in any medium, provided the original work is properly cited. 